\title{
Immunomodulation by Myxospores of Myxococcus xanthus
}

\author{
By C. RUIZ, A. RUIZ-BRAVO,* G. ALVAREZ DE CIENFUEGOS \\ AND A. RAMOS-CORMENZANA \\ Department of Microbiology, Faculty of Pharmacy, University of Granada, Granada, Spain
}

(Received 25 October 1984; revised 9 April 1985)

\begin{abstract}
Glycerol-induced myxospores of Myxococcus xanthus caused non-specific modulation of humoral and cellular immune responses in laboratory animals. The number of cells which formed specific haemolysins in spleens of mice immunized with sheep erythrocytes was increased when $0.5 \times 10^{8}$ myxospores were inoculated $2 \mathrm{~d}$ after the erythrocytes, and decreased when myxospores were injected $2 \mathrm{~d}$ before or at the same time as the erythrocytes. Both the IgG primary response and the secondary response to erythrocytes were decreased in rabbits after pretreatment with $2 \times 10^{8}$ myxospores per rabbit. Delayed-type hypersensitivity to sheep erythrocytes was also suppressed in mice after intraperitoneal (i.p.) injection of $0.3 \times 10^{8}$ myxospores. One day after i.p. injection of myxospores, neither an inflammatory response nor bone marrow cell depletion was observed in mice. These results support the idea that $M$. xanthus myxospores possess diverse immunomodulation properties apparently due to factors different from the classical LPS of Gram-negative bacteria.
\end{abstract}

\section{INTRODUCTION}

Cells of a number of microbial species as well as various bacterial products possess immunomodulating properties (reviewed by White, 1976; Stewart-Tull, 1980).

The fruiting myxobacteria comprise a group of closely related Gram-negative bacteria which are typified by a life cycle quite remarkable in view of their prokaryotic nature. Under certain conditions the cells aggregate and cooperatively construct macroscopic fruiting bodies within which the individual cells convert to myxospores (Dworkin, 1966). Myxospore formation can be induced in liquid culture by a variety of techniques (Dworkin \& Gibson, 1964; Burchard, 1975).

In a previous work, we demonstrated that an induced myxospore suspension of Myxococcus xanthus modulated the humoral response to sheep red blood cells (SRBC) in mice, whereas vegetative cells failed to do so (Ruiz et al., 1984). It appears that the existence of different immunomodulation factors in the vegetative cells and in the myxospores of $M$. xanthus resembles the situation in Bacillus megaterium (Ruiz-Bravo et al., 1981).

The aim of this work was to study the possible immunomodulation effect of induced myxospores of $M$. xanthus CCM 3494 on several parameters of immunity.

\section{METHODS}

Animals. Male Balb/c mice were bred in our laboratory from breeding pairs originally obtained from the Department of Immunology, London Hospital Medical School, UK. Experimental groups were made by random selection of $20-25 \mathrm{~g}$ animals $6-8$ weeks of age.

Rabbits weighing $2 \cdot 5-3.0 \mathrm{~kg}$ were purchased locally.

Preparation of bacteria. Myxococcus xanthus CCM 3494 was grown with aeration at $30^{\circ} \mathrm{C}$ in liquid medium containing $1 \%(\mathrm{w} / \mathrm{v})$ Casitone (Difco) and $0.2 \%(\mathrm{w} / \mathrm{v}) \mathrm{MgSO}_{4} \cdot 7 \mathrm{H}_{2} \mathrm{O}$. Myxospore formation was induced by the

\footnotetext{
Abbreviations: SRBC, sheep red blood cells; PFC, splenic haemolytic plaque-forming cells; DTH, delayed-type hypersensitivity; 2ME, 2-mercaptoethanol; i.p., intraperitoneal(ly); i.v. intravenous(ly); s.c. subcutaneous(ly).
} 
addition of glycerol to a final concentration of $4.6 \%$ (w/v) as described by Dworkin \& Gibson (1964). Myxospores were washed, suspended in phosphate-buffered saline (PBS) $(0.85 \% \mathrm{NaCl}$ in $0.15 \mathrm{M}$-sodium phosphate, $\mathrm{pH} 7.2)$, and concentrated to a density of $2.5 \times 10^{8}$ myxospores $\mathrm{ml}^{-1}$. The total cell number was determined using a PetroffHausser counting chamber.

Antigen. SRBC were washed three times, resuspended in PBS and stored at $4{ }^{\circ} \mathrm{C}$ until needed.

Antibody-forming cell assay. Mice were injected i.p. with $0.2 \mathrm{ml}$ of the myxospore suspension $\left(0.5 \times 10^{8}\right.$ myxospores) (i) $2 \mathrm{~d}$ before, (ii) the same day as, or (iii) $2 \mathrm{~d}$ after i.p. immunization with $1 \times 10^{9} \mathrm{SRBC}$. Mice were killed $4 \mathrm{~d}$ after SRBC injection and splenic haemolytic plaque-forming cells (PFC) were counted by the technique of Cunningham \& Szenberg (1968).

Serum antibody assay. Rabbits were injected i.p. or intravenously (i.v.) with $0.8 \mathrm{ml}$ of the myxospore suspension containing $2.5 \times 10^{8}$ myxospores $\mathrm{ml}^{-1}$. Control animals received $0.8 \mathrm{ml}$ sterile PBS. All animals were injected i.p. with $2 \mathrm{ml} 10 \%(\mathrm{v} / \mathrm{v}) \mathrm{SRBC}$ in PBS, 4 and $26 \mathrm{~d}$ after inoculation with the myxospore preparation.

Blood samples were withdrawn from the marginal ear vein at various time intervals; after coagulation and clot separation, serum titres were determined. For the haemagglutination assay, twofold dilutions of serum in PBS were prepared in microtitre plates with round-bottomed wells. A $50 \mu \mathrm{l}$ sample of a $0.5 \%(\mathrm{v} / \mathrm{v})$ SRBC suspension was added to $50 \mu \mathrm{l}$ of the diluted serum. To determine the titre of antibodies resistant to 2-mercaptoethanol (2ME), serum was preincubated with $1.4 \%(\mathrm{v} / \mathrm{v}) 2 \mathrm{ME}$ at $37^{\circ} \mathrm{C}$ for $1 \mathrm{~h}$ (Yashphe, 1972). Haemagglutinating titres were determined after $4 \mathrm{~h}$ in all tests.

Assay with peritoneal cells. Mice were killed 24 and $72 \mathrm{~h}$ after i.p. inoculation with $0.2 \mathrm{ml}$ of the myxospore suspension. Both peritoneal cell harvest and culture were performed as described previously (Fishel et al., 1976; Yarkoni et al, 1977), with minor modifications. Briefly, mice received i.p. $3 \mathrm{ml}$ of medium 199 with $10 \%$ (v/v) heat-inactivated calf serum and sodium heparinate. Peritoneal fluid was withdrawn, centrifuged, and the sediment resuspended in fresh medium. Viable cells were counted and suspensions distributed into plastic Petri dishes. After $2 \mathrm{~h}$ incubation at $37^{\circ} \mathrm{C}$, cells which failed to adhere were removed and counted. For the phagocytosis assay, the adherent cell monolayers were washed with fresh medium containing $10^{8} \mathrm{SRBC}$. After incubation at $37^{\circ} \mathrm{C}$ for $1 \mathrm{~h}$, the monolayers were washed, fixed and stained with Giemsa stain. The number of phagocytic cells were counted among at least 200 adherent cells.

Collection and quantification of bone marrow cells. Bone marrow cells were collected by dissecting one or both femurs of each mouse, cutting the bone at the metaphysis, and flushing the marrow cavity with 1.0 ml medium 199 (with heparin) using a 27-gauge needle. The cell suspension was centrifuged at $400 \mathrm{~g}$ for $10 \mathrm{~min}$ and the sediment was resuspended in $2 \mathrm{ml}$ medium 199. Viable cells were counted by the Trypan blue exclusion method.

Delayed-type hypersensitivity (DTH) determined by footpad swelling. As a pretreatment, mice were injected subcutaneously (s.c.) or i.p. with a mixture of $0.125 \mathrm{ml} \mathrm{SRBC}(2 \%, \mathrm{v} / \mathrm{v}$, in PBS) and $0 \cdot 125 \mathrm{ml}$ of the myxospore suspension. Control mice received only $0.25 \mathrm{ml}$ of a $1 \%(\mathrm{v} / \mathrm{v})$ suspension of SRBC in PBS, in the same way as the treated mice. After $7 \mathrm{~d}$, mice were injected in the left hind footpad with $0.05 \mathrm{ml} \mathrm{SRBC}(1 \%, \mathrm{v} / \mathrm{v}$, in PBS), and in the right hind footpad with $0.05 \mathrm{ml}$ PBS as the control. The thickness of the stimulated and the control footpads was measured with a dial-gauge caliper $24 \mathrm{~h}$ after the elicitation. The difference in footpad thickness was expressed in units of $0 \cdot 1 \mathrm{~mm}$.

Statistics. The differences between mean results in animals treated with myxospores of $M$. xanthus and controls were analysed by Student's $t$-test. Statistical significance was determined at the $P<0.05$ level.

\section{RESULTS}

Modulation of the PFC response by $M$. xanthus myxospores. When myxospores were administered to mice $2 \mathrm{~d}$ before or on the same day of immunization with SRBC, the PFC response was suppressed (Fig. 1). In contrast, the injection of myxospores $2 \mathrm{~d}$ after SRBC significantly enhanced the PFC response.

Effect of M. xanthus myxospores on haemagglutination titres to $S R B C$. Haemagglutination titres of the serum of rabbits pretreated with $M$. xanthus myxospores are shown in Fig. 2. The primary response was enhanced by myxospores injected i.v. However, pretreatment with myxospores resulted in suppression of the secondary response, irrespective of the route of inoculation. Qualitative changes in the primary response were caused by both i.v. and i.p. injection of myxospores. Thus, the amount of $2 \mathrm{ME}$-labile antibodies (IgM) increased while the amount of $2 \mathrm{ME}-$ resistant antibodies ( $\mathrm{IgG})$ decreased as a result of pretreatment of the animals.

Peritoneal leucocyte response to the inoculation of $M$. xanthus myxospores. The effect of pretreatment with myxospores on the peritoneal cell populations is shown in Table 1. A 


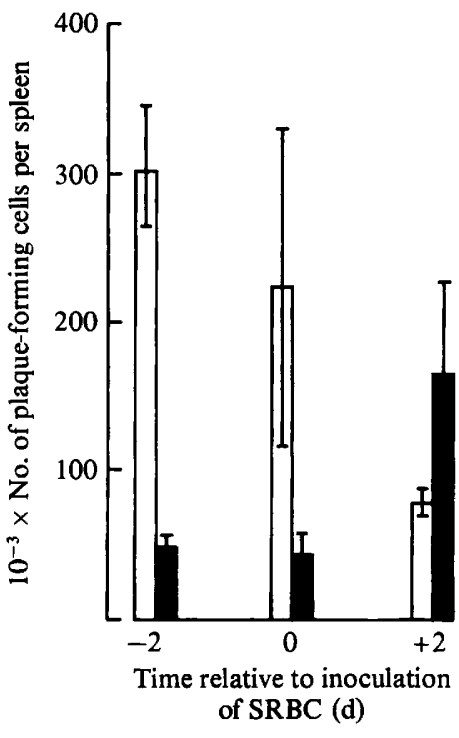

Fig. 1
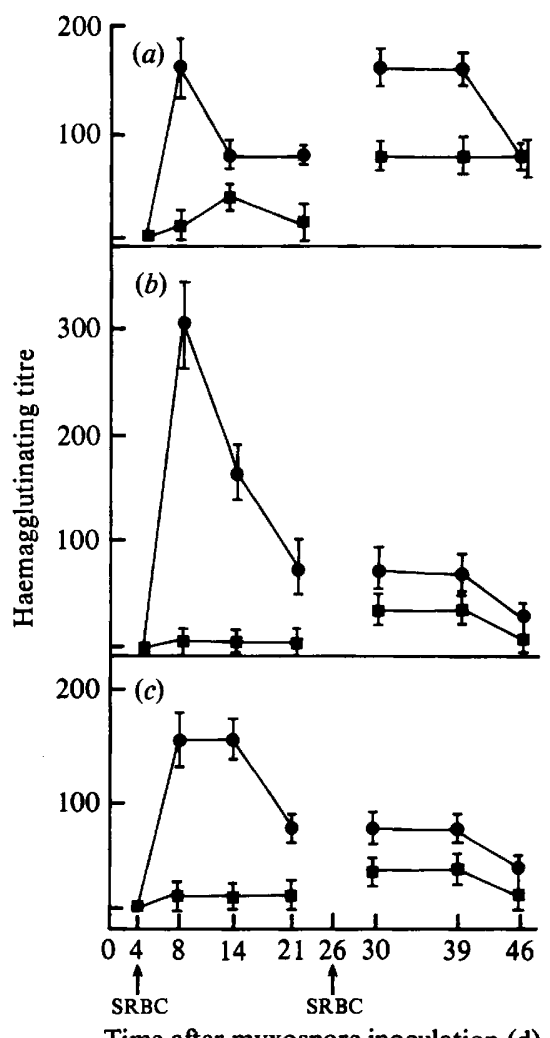

Time after myxospore inoculation (d)

Fig. 2

Fig. 1. Modulation of the PFC response to SRBC in mice by myxospores of $M$. xanthus. $\square$, Control mice; myxospore-treated mice. The values are means of results from at least six mice $\pm 95 \%$ confidence limits.

Fig. 2. Effect of pretreatment with myxospores of $M$. xanthus on the primary and secondary serum antibody response to SRBC in rabbits. (a) Control rabbits (saline on day 0$) ;(b)$ treated rabbits $\left(2 \times 10^{8}\right.$ myxospores per rabbit on day 0 injected i.v.); $(c)$ treated rabbits $\left(2 \times 10^{8}\right.$ myxospores per rabbit on day 0 injected i.p.). 0 , Total haemagglutinating titre;, $2 \mathrm{ME}-$ resistant haemagglutinating titre. The results are means of five experiments $\pm 95 \%$ confidence limits.

Table 1. Peritoneal cell response to $M$. xanthus myxospores in mice

\begin{tabular}{|c|c|c|c|c|c|}
\hline \multirow[b]{2}{*}{ Pretreatment } & \multirow{2}{*}{$\begin{array}{l}\text { Killed on } \\
\text { day }\end{array}$} & \multirow{2}{*}{$\begin{array}{c}10^{-6} \times \text { No. of } \\
\text { peritoneal } \\
\text { cells* }\end{array}$} & \multirow{2}{*}{$\begin{array}{l}\text { Adherent } \\
\text { cells }(\%)\end{array}$} & \multicolumn{2}{|c|}{ Adherent phagocytes } \\
\hline & & & & Percentage $†$ & Phagocytic index \\
\hline Saline & 1 & $6 \cdot 4 \pm 2 \cdot 4$ & $74 \cdot 1 \pm 7 \cdot 0$ & $18.4 \pm 1.5$ & $1.2 \pm 0.1$ \\
\hline Myxospores $\S$ & 1 & $6 \cdot 7 \pm 1 \cdot 3$ & $69.8 \pm 8.1$ & $24 \cdot 0 \pm 5 \cdot 2$ & $2 \cdot 7 \pm 0 \cdot 1 \|$ \\
\hline Saline & 3 & $8 \cdot 2 \pm 1 \cdot 2$ & $80 \cdot 1 \pm 7 \cdot 3$ & $18.5 \pm 1.5$ & $1 \cdot 2 \pm 0 \cdot 1$ \\
\hline Myxospores§ & 3 & $10 \cdot 3 \pm 1 \cdot 0 \|$ & $78.4 \pm 1.5$ & $28 \cdot 3 \pm 4 \cdot 7 \|$ & $2 \cdot 9 \pm 0.4 \|$ \\
\hline
\end{tabular}

* Arithmetic means of results from at least six mice $\pm 95 \%$ confidence limits.

$\dagger$ Percentage relative to the total number of adherent cells.

$\ddagger$ Mean no. of ingested SRBC per phagocytic cell.

$\S 0.5 \times 10^{8}$ myxospores inoculated per mouse.

$\|$ Significantly different from the control $(P<0.05)$. 
Table 2. DTH response to $S R B C$ in mice inoculated with $M$. xanthus myxospores

$\begin{array}{lc}\text { Treatment (route) } & \begin{array}{c}\text { Foodpad swelling* } \\ (0.1 \mathrm{~mm} \text { units) }\end{array} \\ \text { Saline (i.p.) } & 6.8 \pm 0.9 \\ \text { Myxospores (i.p.) } \dagger & 2.8 \pm 1.9 \quad(P=0.01) \\ \text { Saline (s.c.) } & 7.2 \pm 1.2 \quad \\ \text { Myxospores (s.c.) } \dagger & 6.7 \pm 3.5 \quad(\mathrm{Ns})\end{array}$

* Difference in footpad thickness (arithmetic means of results from at least six mice $\pm 95 \%$ confidence limits; $P$ values obtained by the $t$ test). NS, Not significant.

$\dagger 0.3 \times 10^{8}$ myxospores inoculated per mouse.

moderate but significant inflammatory response was found $3 \mathrm{~d}$ after inoculation of myxospores. Adherent cells did not show significant changes in the treated animals, but the phagocyte fraction of adherent cells was significantly increased $3 \mathrm{~d}$ after inoculation. The number of SRBC ingested per phagocytic cell was significantly increased both $1 \mathrm{~d}$ and $3 \mathrm{~d}$ after myxospore inoculation.

Bone marrow cellularity in mice after inoculation of $M$. xanthus myxospores. The possible effect of i.p. injection of myxospores on bone marrow cell populations was evaluated $24 \mathrm{~h}$ after injection. The counts of nucleated cells per femur were $8.7 \pm 1.53 \times 10^{6}$ for control mice injected with saline, and $9.0 \pm 1.85 \times 10^{6}$ for mice injected with $0.5 \times 10^{8}$ myxospores (values are arithmetic means of at least six mice $\pm 95 \%$ confidence limits). These results indicated that myxospores did not alter the number of bone marrow nucleated cells.

Effect of $M$. xanthus myxospores on the DTH response to $S R B C$. The results in Table 2 indicate that myxospores suppressed the DTH response when they were inoculated i.p. but not when they were inoculated s.c.

\section{DISCUSSION}

The results presented here show that the inoculation of laboratory animals with myxospores of $M$. xanthus causes modulation of the humoral and cellular immune responses against unrelated antigens.

Immunomodulation induced by bacteria provides a useful experimental system in immunobiological studies (Schwab, 1977). A bacterial cell represents a complex association of antigens, mitogens and adjuvants, which may act on several levels of the immune system (Schwab, 1977; Johnson, 1981). In the case of myxospores, it is difficult to attribute their immunomodulation properties to a defined component. In Gram-negative bacteria the lipopolysaccharide (LPS) is recognized as a major fraction with adjuvant properties (Rosenstreich \& Mergenhagen, 1975; Koening \& Hoffman, 1979). However, the modulation pattern of the antibody-forming cell response in mice by $M$. xanthus myxospores was quite different from that reported for the LPS from Gram-negative bacteria (Diamantstein et al., 1976; Nakano et al., 1976; Covert \& Zarkower, 1971). Furthermore, no LPS has been described among the components of myxospore cells (Sutherland, 1976). LPS and LPS-containing cells have been recognized as potent inducers of rapid inflammatory responses (Snyderman \& Verghese, 1980) and bone marrow cell depletion in mice (Behling \& Nowotny, 1981). This was not observed in our assays with $M$. xanthus myxospores. It seems reasonable to assume that bacterial cell fraction(s) other than LPS may have been responsible for the immunomodulation by myxospores in our studies.

Our results support several hypotheses which may explain the mechanisms of immunomodulation by $M$. xanthus myxospores. It appears that the regulatory function of T-suppressor $\left(T_{s}\right)$ cells may be very important in these mechanisms. Thus, suppression of the DTH response in mice after myxospore inoculation may be attributable to $T_{s}$ cell stimulation, as reported for other 
bacterial adjuvants (Galleli et al., 1981). In the same way, suppression of both the IgG primary response and the secondary response to $\mathrm{SRBC}$ in rabbits may be explained in terms of $\mathrm{T}_{\mathrm{s}}$-cell stimulation, since it may be comparable to the partial conversion to a T-cell-dependent antibody response in T-independent responses; there is some evidence that limitation of IgG production in T-cell-independent responses is due to active participation of T-cells (Schuler et al., 1982; McKearn et al., 1982). We conclude that $M$. xanthus myxospores provide an interesting inducer of immunomodulation, in which the active bacterial cell material appears to differ from that in Gram-negative bacteria. Further work is required for a better understanding of the immunomodulation mechanisms of this system.

\section{REFERENCES}

Behling, U. H. \& NowotNy, A. (1981). Immunostimulation by LPS and its derivatives. In Immunomodulation by Bacteria and Their Products, pp. 165179. Edited by H. Friedman, T. W. Klein \& A. Szentivanyi. New York: Plenum Press.

BurChaRd, R. P. (1975). Myxospore induction in a nondispersed growing mutant of Myxococcus xanthus. Journal of Bacteriology 122, 302-306.

COVERT, J. B. \& Zarkower, A. (1971). Influence of Escherichia coli lipopolysaccharide on histamineforming capacity and antibody formation in lymphoid tissues. Infection and Immunity 4, 452-455.

Cunningham, A. J. \& Szenberg, A. (1968). Further improvements in the plaque technique for detecting single antibody forming cells. Immunology 14, 599600.

Diamantstein, T., Keppler, W., Blitstein-WilLINGER, E. \& BENAFRAIN, S. (1976). Suppression of the primary immune response in vivo to sheep red blood cells by B cell mitogens. Immunology 30, 401407.

DWORKIN, M. (1966). Biology of the myxobacteria. Annual Review of Microbiology 20, 75-106.

Dworkin, M. \& Gibson, S. M. (1964). A system for studying microbial morphogenesis: rapid formation of microcysts in Myxococcus xanthus. Science 146, 243-244.

Fishel, W., Halkias, D. G., Klein, T. W. \& SZEnTIVANYI, A. (1976). Characteristics of cells present in peritoneal fluids of mice injected intraperitoneally with Bordetella pertussis. Infection and Immunity 13, 263-272.

Galleli, A., Le Ganec, Y. \& Chedid, L. (1981). Increased resistance and depressed delayed-type hypersensitivity to Listeria monocytogenes induced by pretreatment with lipopolysaccharide. Infection and Immunity 31, 88-94.

Johnson, A. G. (1981). Microbial adjuvants and immune responsiveness. In Immunomodulation by Bacteria and Their Products, pp. 1-11. Edited by $\mathbf{H}$. Friedman, T. W. Klein \& A. Szentivanyi. New York: Plenum Press.

Koening, S. \& Hoffmann, M. K. (1979). Bacterial lipopolysaccharide activates suppressor B lymphocytes. Proceedings of the National Academy of Sciences of the United States of America 76, 46084612.

McKearn, J. P., Pasplay, J. W., Slack, J., Braum, C. \& DAVIE, J. M. (1982). B cell subsets and differential responses to mitogens. Immunological Reviews 64, 523.

Nakano, M., Tanabe, M. J., Saito, T. \& Shimizu, T.
(1976). Immunosuppressive effect of bacterial lipopolysaccharide on antibody response. Japanese Journal of Microbiology 20, 53-58.

Rosenstreich, D. L. \& Mergenhagen, S. E. (1975). Interaction of endotoxin with cells of the lymphoreticular system: cellular basis of adjuvanticity. In Microbiology-1975, pp. 320-326. Edited by D. Schlessinger. Washington, DC: American Society for Microbiology.

Ruiz, C., Alvarez de Cienfuegos, G., RamosCormenzana, A. \& Ruiz-Bravo, A. (1984). Actividad immunomoduladora en el género Myxococcus. Microbiolgia española 37, 47-54.

Ruiz-Bravo, A., Kouwatli, K., Alvarez de CienFUEGos, G. \& Ramos-CoRmenzanA, A. (1981). Immunomodulation in mice by Bacillus megaterium and its dependence on culture conditions. Immunology Letters 3, 39-43.

Schuler, W., Lehle, G., Weiler, E. \& Kolsch, E. (1982). Immune response against the $T$-independent antigen $\alpha-(1-3)$ dextran. I. Demonstration of an unexpected IgG response of athymic and germ-freeraised enthymic BALB/c mice. European Journal of Immunology 12, 120-125.

SchwaB, J. H. (1977). Modulation of the immune response by bacteria. In Microbiology-1977, pp. 366-373. Edited by D. Schlessinger. Washington, DC: American Society for Microbiology.

SNYderman, R. \& Verghese, M. W. (1980). Genetic control of leukocyte response to endotoxic lipopolysaccharide in mice. In Microbiology-1980, pp. 2529. Edited by D. Schlessinger. Washington, DC: American Society for Microbiology.

Stewart-Tull, D. E. S. (1980). The immunological activities of bacterial peptidoglycans. Annual Review of Microbiology 34, 311-340.

Sutherland, I. W. (1976). Novel surface polymer changes in development of Myxococcus spp. Nature, London 259, 46-47.

WHITE, R. G. (1976). The adjuvant effect of microbial products on the immune response. Annual Review of Microbiology 30, 579-600.

YARKONI, E., WANG, L. \& BEKIERKUNST, A. (1977). Stimulation of macrophages by "cord factor" and by heat killed and living BCG. Infection and Immunity 18, 1-8.

YASHPHE, D. J. (1972). Modulation of the immune response by a methanol-insoluble fraction of attenuated tubercle bacilli (BCG). II. Relationship of antigen doses to heightened primary and secondary immune responses to sheep red blood cells. Clinical and Experimental Immunology 12, 497-506. 